\title{
Barbiturate Intoxication
}

National Cancer Institute

\section{Source}

National Cancer Institute. Barbiturate Intoxication. NCI Thesaurus. Code C28214.

Disturbances in psychophysiological functions and responses as a result of administration or ingestion of a member of the barbiturate class of central nervous system depressants. 